\title{
Kemampuan Literasi Matematika Dalam Memecahkan Masalah Matematika Pada Siswa Kelas VIII SMP Negeri 2 Woha
}

\author{
${ }^{1}$ Nurlailatun Ramdani, ${ }^{2}$ Nunung Fatimah \\ ${ }^{1}$ Program Studi Pendidikan Matematikan STKIP Harapan Bima, Jl. Kancoa Rida, Ds. Kananga, \\ Kec. Bolo Bima, Indonesia 84161 \\ ${ }^{2}$ Program Studi PGSD, STKIP Taman Siswa Bima, Jl. Pendidikan Taman Siswa Nomor 1 Bima, \\ Indonesia 84171 \\ Email : nurlailatun2301@gmail.com ${ }^{1}$,nunungfatimah95@gmail.com²
}

\begin{abstract}
This study aims to describe the ability of mathematical literacy in solving mathematical problems in class VIII SMP Negeri 2 Woha. This research is a qualitative research using a descriptive approach. Data collection was carried out on class VIII students of SMP Negeri 2 Woha in the 2020/2021 academic year and the selection of subjects was based on the level of students' mathematical abilities. The research instrument used was a matter of students' mathematical literacy skills in solving mathematical problems. Data collection techniques were carried out by tests and interviews. The results obtained from students with high categories are able to carry out several stages of the student literacy process in solving mathematical problems well in the section formulating, applying concepts, facts, procedures, and reasoning but in the problem section, application, problem finding and drawing conclusions students have not maximum work and explain when to interview.
\end{abstract}

Keywords: Mathematical Literacy, Problem Solving Skill

\begin{abstract}
Abstrak
Penelitian ini bertujuan untuk mendeskripsikan kemampuan literasi matematika dalam memecahkan masalah matematika pada siswa kelas VIII SMP Negeri 2 Woha. Penelitian ini merupakan penelitian kualitatif dengan menggunakan pendekatan deskriptif. Pengambilan data dilakukan pada siswa kelas VIII SMP Negeri 2 Woha tahun ajaran 2020/2021 dan pemilihan subjek berdasarkan tingkat kemampuan matematis siswa. Instrumen penelitian yang digunakan adalah lembar soal kemampuan literasi matematis siswa dalam memecahkan masalah matematika. Teknik pengumpulan data dilakukan dengan tes dan wawancara. Hasil penelitian yang diperoleh dari siswa dengan kategori tinggi yaitu siswa mampu melakukan beberapa tahapan proses literasi dalam memecahkan masalah matematika dengan baik pada bagian merumuskan masalah, menerapkan konsep, fakta, prosedur, dan penalaran namun pada bagian menafsirkan, menerapkan, mengevaluasi hasil perhitungan dan menari kesimpulan siswa belum maksimal dalam mengerjakan maupun menjelaskan ketika peneliti mewawancarai.
\end{abstract}

Kata kunci: Literasi; Matematika; Pemecahan Masalah; matematika

\section{PENDAHULUAN}

Kebutuhan yang mutlak bagi kehidupan manusia adalah pendidikan karena melalui pendidikan seseorang dapat mendewasakan dirinya melalui upaya pengajaran dan latihan proses perbuatannya. Selain dari itu, kemajuan suatu bangsa yang diperoleh sampai saat ini juga merupakan berkat proses dari pendidikan. Hal ini didukung oleh Undang-Undang No 20 tahun 2003 tentang Sistem Pendidikan Nasional Pasal 3 yang berbunyi bahwa pendidikan sangat penting untuk mengembangkan kemampuan dan membentuk watak serta peradaban bangsa yang bermartabat dalam rangka mencerdaskan kehidupan bangsa sehingga diperlukan suatu pendidikan yang berkualitas. Kualitas pendidikan mengacu pada proses pendidikan dan hasil pendidikan (Nurvicalesti., Rachmani \& Nuriana, 2019). Hasil pendidikan di seluruh dunia dapat diketahui dengan adanya Programme for International Student Assessment (PISA) yangmana tujuannya yaitu untuk mengevaluasi sistem pendidikan dengan menguji kemampuan dan pengetahuan siswa umur 15 tahun (Kemendikbud, 2019). Lebih lanjut, hasil pendidikan di bidang matematika yaitu untuk nilai rata-rata terendah diperoleh pada tes PISA Tahun 2003 sebesar 360, nilai rata-rata tertinggi diperoleh pada tes PISA Tahun 2006 sebesar 391 sedangkan nilai ratarata tes PISA Tahun 2018 sebesar 379. Dari nilai rata-rata tes PISA tersebut menunjukan 
bahwa pergerakannya fluktuatif sehingga masih belum memuaskan tingkat kemampuan matematika siswa.

Sari (2015) \& Fathani (2016) mengemukakan tuntutan kemampuan matematika siswa yaitu memiliki kemampuan bernalar yang logis dan kritis dalam memecahkan masalah sehingga tidak sekedar memiliki kemampuan berhitung saja. Selanjutnya, dalam memecahan masalah tidak hanya memecahkan soal rutin akan tetapi lebih kepada permasalahan yang dihadapi sehari-hari (Zahro et al, 2020; Rachmantika \& Wardono, 2019). Dari paparan di atas maka dapat disimpulkan bahwa kemampuan matematis tersebut adalah kemampuan literasi matematis. Wati, Sugiyanti dan Muhtaro (2019) menyatakan bahwa literasi dari sisi tradisional dipandang sebagai kemampuan membaca dan menulis. Namun untuk literasi matematika menurut Zahro., et al (2020) adalah pengetahuan untuk mengetahui dan menerapkan dasar matematika di dalam kehidupan sehari-hari. Dari beberapa pendapat di atas menunjukan bahwa kemampuan literasi matematika dalam memecahkan masalah matematika sangat terikat satu sama lain hal ini didukung dengan pendapat Stacey (2011), de Lange (2003), Ojose (2011) \& Sari (2017) yang menyatakan bahwa literasi matematika adalah kemampuan menyusun pertanyaan, merumuskan permasalahan, memecahkan masalah, menarik kesimpulan dari suatu permasalahan dan dapat mengomunikasikan matematika dari suatu permasalahan yang ada. Maka dari itu, literasi matematika sangatlah penting dikuasai akan tetapi tidak hanya menguasainya dalam konteks aritmatik melainkan juga membutuhkan penalaran dan analitisnya dalam memecahkan masalah matematis sebab begitu banyak permasalahan yang dihadapi dalam kehidupan sehari-hari untuk menyelesaikannya.

Pentingnya literasi matematika harus sebanding dengan hasil yang dicapai khususnya dalam pembelajaran matematika di sekolah SMP/MTs. Namun kenyataan di lapangan, literasi matematika belum terlatih secara maksimal. Dari hasil observasi yang peneliti lakukan terhadap siswa kelas VIII SMP Negeri 2 Woha pada saat proses pembelajaran matematika didapatkan bahwa ketika guru memberikan soal matematika nonrutin tidak ada siswa yang mampu menyelesaikan masalah matematika dengan tepat melainkan siswa menyelesaikannya dengan beberapa kesalahan baik itu kesalahan dalam merumuskan, kesalahan dalam melakukan perhitungan maupun kesalahan yang dilakukan siswa pada proses penyelesaian lainnya. Lebih dalam lagi peneliti mengali informasi terhadap siswa yaitu peneliti melakukan wawancara terhadap beberapa siswa dan hasil wawancarannya juga menunjukan bahwa (1) siswa belum terbiasa menyelesaikan soal nonrutin sehingga menyebabkan siswa lebih suka diberikan soal langsung tanpa perlu penalaran dalam menyelesaikan soal (2) kurangnya ketersediaan buku tes matematika yang menuntut siswa dalam memecahkan masalah sehari-hari. Hal tersebut sejalan dengan hasil penelitian yang dilakukan Novita, Zulkardir, Hartono (2012) yangmana siswa belum terbiasa dalam mengerjakan soal kontekstual termasuk soal matematika PISA sehingga siswa hanya terbiasa memperoleh dan menggunakan pengetahuan matematika formal di kelas. Selain dari itu, ada beberapa hasil studi ilmiah juga yang memaparkan bahwa siswa di Indonesia tidak terbiasa diberikan soal nonrutin yang berbau pemodelan dimana untuk menyelesaikan soal dibutuhkan kemampuan menerjemahkan masalah sehari-hari kedalam bentuk matematika formal (Edo, 2012; Afriyanti,Wardono, \& Kartono, 2018; Dewantara, 2019).

Dari semua permasalahan yang disampaikan maka diperlukan analisis lebih lanjut sehubungan dengan kemampuan literasi matematika siswa dalam memecahkan masalah matematika pada siswa kelas VIII SMP Negeri 2 Woha. Penelitian yang dilakukan akan memiliki nilai kebaruan yang terletak pada hasil deskripsi kemampuan literasi matematika siswa dalam memecahkan masalah matematika pada siswa kelas VIII SMP Negeri 2 Woha. 


\section{METODE}

Penelitian ini bertujuan untuk mendeskripsikan kemampuan literasi matematika dalam memecahkan masalah matematika pada siswa kelas VIII SMP Negeri 2. Jenis penelitian yang digunakan adalah penelitian deskriptif dengan pendekatan kualitatif. Peneliti memilih tempat penelitian di SMP Negeri 2 Woha. Subjek penelitian yaitu siswa kelas VIII.1. Instrumen penelitian yang digunakan: (1) instrumen utama adalah peneliti sendiri (2) instrumen pendukung adalah observasi, tes dan wawancara. Pengecekan keabsahan data dalam penelitian ini difokuskan pada "Kemampuan Literasi Matematika dalam Memecahkan Masalah Matematika pada Siswa Kelas VIII SMP Negeri 2 Woha" dengan teknik pengumpulan data melalui triangulasi data sedangkan analisis data penelitian meliputi reduksi data, penyajian data dan menarik kesimpulan.

\section{HASIL DAN PEMBAHASAN}

Subjek dalam penelitian ini yaitu siswa yang memiliki kemampuan matematis tinggi, mampu berkomunikasi dengan baik dan sesuai dengan rekomendasi dari guru. Peneliti memberikan soal nonrutin untuk dikerjakan oleh subjek, Soal yang diberikan tidak terlepas dari materi pelajaran matematika yang dipelajari sebelumnya. Setelah subjek mengerjakan selanjutnya peneliti mendeskripsikan hasil pengerjaan subjek berdasarkan instrumen yang diadaptasi dari OECD (2010) yaitu setiap proses literasi matematika siswa dalam memecahkan masalah matematika memiliki aktivitas yang bisa diketahui seperti dalam tabel di bawah ini:

Tabel 1. Kemampuan literasi matematika dalam Memecahkan Masalah Matematika

\begin{tabular}{|c|c|}
\hline $\begin{array}{l}\text { Kemampuan } \\
\text { Literasi } \\
\text { Matematika }\end{array}$ & Aktivitas \\
\hline $\begin{array}{l}\text { Merumuskan } \\
\text { masalah secara } \\
\text { matematis }\end{array}$ & $\begin{array}{lr}\text { Memahami } & \text { struktur } \\
\text { matematika } & \text { dalam } \\
\text { permasalahan } & \text { atau } \\
\text { situasi }\end{array}$ \\
\hline
\end{tabular}

\begin{tabular}{|c|c|}
\hline & $\begin{array}{l}\text { Mengidentifikasi } \\
\text { aspek-aspek } \\
\text { matematika dalam } \\
\text { permasalahan yang } \\
\text { ada serta } \\
\text { mengidentifikasi } \\
\text { variabel yang penting } \\
\text { yaitu dari apa yang } \\
\text { diketahui dan } \\
\text { ditanyakan. } \\
\text { Membuat model } \\
\text { matematika dan } \\
\text { menyederhanakan } \\
\text { masalah yang ada }\end{array}$ \\
\hline $\begin{array}{l}\text { Menerapkan } \\
\text { konsep, fakta, } \\
\text { prosedur dan } \\
\text { penalaran }\end{array}$ & $\begin{array}{ll}\text { Merancang } & \text { dan } \\
\text { mengimplementasika } \\
\text { n strategi } & \text { untuk } \\
\text { menemukan } & \text { solusi } \\
\text { matematika } & \\
\end{array}$ \\
\hline $\begin{array}{l}\text { Menafsirkan, } \\
\text { menerapkan dan } \\
\text { mengevaluasi } \\
\text { hasil } \\
\text { perhitungan }\end{array}$ & $\begin{array}{ll}\text { Memberikan } & \\
\text { penguatan dari hasil } \\
\text { perhitungan } & \text { yang } \\
\text { diperoleh } & \\
\text { Menjelaskan } & \\
\text { mengapa } & \text { hasil } \\
\text { matematika } & \text { dapat } \\
\text { atau tidak. } & \\
\end{array}$ \\
\hline
\end{tabular}

Sumber: OECD (2010)

1. Hasil Tes Tertulis

a. Merumuskan masalah secara matematis

Subjek PM mampu merumuskan masalah secara matematis terlihat bahwa subjek mampu memahami struktur matematika dalam permasalahan atau situasi yang ada dan mengidentifikasi aspek-aspek matematika dalam permasalahan yang ada serta mengidentivikasi variabel yang penting dari apa yang diketahui dan ditanyakan, selanjutnya langkah terakhir yaitu mempu membuat model matematika dan menyelesaikan masalah yang ada. Berikut hasil pengerjaan subjek PM pada bagian merumuskan masalah secara matematis: 

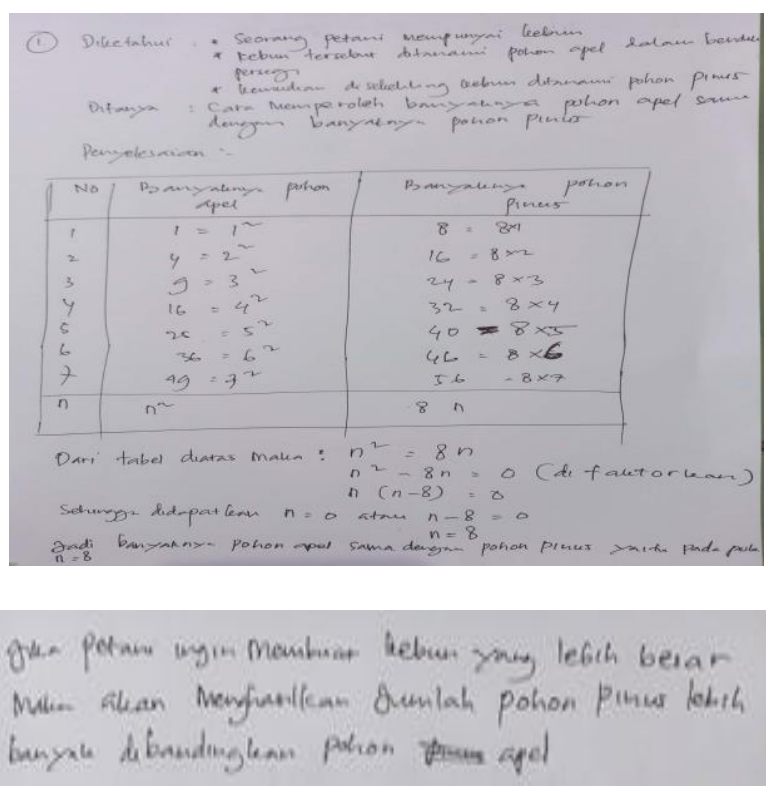

Gambar 1.1 Hasil Tes Tertulis Subjek PM

Gambar di atas menunjukan hasil pengerjaan tes tertulis subjek PM. Subjek PM mampu memahami struktur matematika dalam permasalah atau situasi yang ada dengan tepat menuliskan apa yang diketahui dalam soal yaitu (1) seorang petani mempunyai kebun (2) kebun tersebut ditanami pohon apel dan pohon pinus (3) kemudian disekeliling kebun ditanami pohon pinus. Selanjutnya dalam menuliskan apa yang ditanyakan kurang tepat sebab ada 2 pertanyaan yang ditanyakan dalam soal akan tetapi subjek hanya menuliskan 1 pertanyaan saja yaitu cara untuk memperoleh banyaknya pohon apel samadengan banyaknya pohon pinus.

b. Menerapkan konsep, fakta, prosedur dan penalaran

Subjek PM mampu menerapkan konsep, fakta, prosedur dan penalaran dengan baik untuk mendapatkan solusi. Berikut hasil pengerjaan subjek PM pada bagian ini:

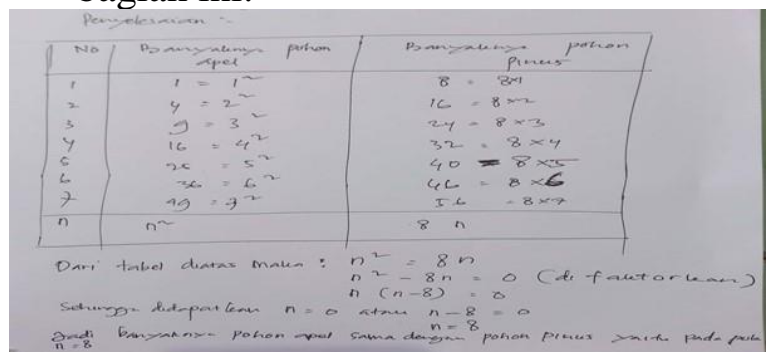

Gambar 1.2 Hasil Tes Tertulis Subjek PM
The petan ungin membuat bebuen zoung lebih berar makn akan menfrasilean Dumlah pohon pinus lebih banyale debaudinglean pohon prowers apel

Gambar 1.3 Hasil Tes Tertulis Subjek PM

Gambar di atas menunjukan hasil pengerjaan tes tertulis subjek PM. Pada Gambar 1.2 Subjek PM mampu Merancang dan mengimplementasikan strategi untuk menemukan solusi matematika dari ilustrasi yang ada pada soal yaitu dengan menuliskan hasil pengerjaannya dalam bentuk, subjek melakukan kekeliruan yaitu pada $\mathrm{n}=6$ yangmana ditulis $8 \times 6=46$ padahal seharusnya $8 \times 6=48 \quad$ walaupun melakukan kesalahan pada perhitungan perkalian tersebut akan tetapi perhitungan selanjutnya subjek PM benar sehingga menemukan hasil akhir yaitu $\mathrm{n}=8$. Pada Gambar 1.3 subjek PM berusaha menuliskan hasil jawabanya pada pertanyaan ke-2 namun subjek melakukan kesalahan dalam menentukan mana yang lebih cepat meningkat antara pohon apel dan pohon pinus.

c. Menafsirkan, menerapkan dan mengevaluasi hasil perhitungan

Subjek PM mampu menafsirkan, menerapkan dan mengevaluasi hasil perhitungan. Berikut hasil pengerjaan subjek PM pada bagian ini:

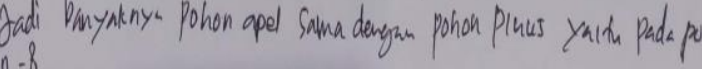

Gambar 1.4 Hasil Tes Tertulis Subjek PM

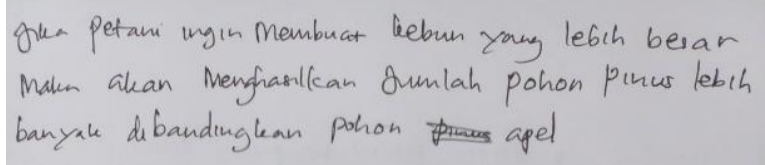

Gambar 1.5 Hasil Tes Tertulis Subjek PM

Gambar di atas menunjukan hasil pengerjaan tes tertulis subjek PM. Pada Gambar 1.4 subjek sudah benar menuliskan kesimpulan sesuai dengan hasil penyelesaian yang didapatkan subjek pada tabel namun utuk menarik kesimpulan pada gamabar 1.4 subjek kurang tepat. 
Tabel 2 Analisis Jawaban Tes Tertulis Subjek PM

\begin{tabular}{|c|c|}
\hline $\begin{array}{c}\text { Tahapan } \\
\text { Kemampuan } \\
\text { Literasi } \\
\text { Matematika }\end{array}$ & $\begin{array}{c}\text { Analisis Jawaban Tes } \\
\text { Tertulis Subjek PM }\end{array}$ \\
\hline $\begin{array}{l}\text { Merumuskan } \\
\text { masalah secara } \\
\text { matematis }\end{array}$ & $\begin{array}{llr}\text { Subjek PM } & \text { mampu } \\
\text { memahami } & & \text { struktur } \\
\text { matematika } & & \text { dalam } \\
\text { permasalah atau } & \text { situasi } \\
\text { yang ada dengan } & \text { tepat } \\
\text { menuliskan apa yang } \\
\text { diketahui dan ditanyakan } \\
\text { dalam soal. }\end{array}$ \\
\hline $\begin{array}{l}\text { Menerapkan } \\
\text { konsep, fakta, } \\
\text { prosedur dan } \\
\text { penalaran }\end{array}$ & $\begin{array}{l}\text { Pada Gambar } 1.2 \text { Subjek } \\
\text { PM mampu merancang dan } \\
\text { mengimplementasikan } \\
\text { strategi untuk menemukan } \\
\text { solusi matematika walaupun } \\
\text { sedikit melakukan } \\
\text { kekeliruan dalam } \\
\text { menuliskan hasil perkalian } \\
\text { yang salah }\end{array}$ \\
\hline $\begin{array}{l}\text { Menafsirkan, } \\
\text { menerapkan } \\
\text { dan } \\
\text { mengevaluasi } \\
\text { hasil } \\
\text { perhitungan }\end{array}$ & $\begin{array}{l}\text { Pada Gambar } 1.4 \text { subjek } \\
\text { sudah benar menuliskan } \\
\text { kesimpulan sesuai dengan } \\
\text { hasil penyelesaian yang } \\
\text { didapatkan subjek namun } \\
\text { pada Gambar } 1.4 \text { subjek } \\
\text { kurang tepat dalam } \\
\text { menuliskan kesimpulannya }\end{array}$ \\
\hline Kesimpulan & $\begin{array}{lr}\begin{array}{l}\text { Subjek PM } \\
\text { melakukan }\end{array} & \begin{array}{r}\text { mampu } \\
\text { tahapan } \\
\text { kemampuan }\end{array} \\
\text { matematika namun belum } \\
\text { maksimal }\end{array}$ \\
\hline
\end{tabular}

\section{Hasil Wawancara Subjek PM}

Selain dari tiga tahap kemampuan literasi matematika yang dikerjakan melalui hasil tulisan maka peneliti juga mengali lebih dalam lagi tiga hal tersebut melalui wawancara. Berikut ini hasil wawancara peneliti terhadap subjek PM:

$$
\begin{array}{rlr}
P_{1}: & \text { Bacakan soal! Setelah } \\
& \text { membaca, Infomasi apa yang } \\
& \text { kamu dapatkan? } \\
P M_{1}: & \begin{array}{l}
\text { Dari soal yang ada, saya } \\
\text { mengetahu apa yang diketahui } \\
\text { dan ditanyakan }
\end{array}
\end{array}
$$

$P_{2} \quad:$ Lalu, sebutkan apa yang diketahui dan ditanyakan?

$P M_{2}$ : Diketahui seorang petani memiliki kebun, lalu kebunnya ditanami pohon apel berbentuk persegi kemudian disekeliling kebun ditanami pohon pinus untuk melindungi tanaman pohon apel dari angin dan ditanyakan ada dua yaitu: (1) bagaimana cara memperoleh banyaknya pohon apel sama dengan banyaknya pohon pinus (2) mana yang akan meningkat lebih cepat antara tanaman pohon apel dengan tanaman pohon pinus

$P_{3} \quad$ : Pada saat mengerjakan hasil tes tertulis, kenapa pada bagian yang ditanyakan cuman satu saja?

$P M_{3}$ : Ia $\mathrm{Bu}$ karena pada saat mengerjakannya saya terlalu terburu-buru sehingga tidak sengaja untuk tidak menulisnya

$P_{4} \quad$ : Berarti kamu sudah mengetahuinya, namun karena terburu-buru mengerjakan sehingga menyebabkan kamu kelupaan untuk menulisnya?

$\mathrm{PM}_{4} \quad$ : Iya $\mathrm{Bu}$

Berdasarkan hasil wawancara peneliti terhadap subjek PM di atas menunjukan bahwa subjek mampu memahami struktur matematika dalam permasalah atau situasi yang ada dengan tepat menjelaskan apa yang diketahui dan ditanyakan dalam soal.

$$
P_{5} \text { : Setelah kamu mengetahui }
$$
permasalahannya, bagaimana kamu merancang dan mengimplementasikan strategi untuk menemukan solusi pada soal?

$P M_{5}$ : Dari soal sudah diberikan ilustrasi mengenai banyaknya pohon apel yaitu $\mathrm{n}=1, \mathrm{n}=$ 2 dan $\mathrm{n}=3$ selanjutnya saya melanjutkan pengerjaan sampai 
menemukan jawaban sesuai apa yang ditanyakan dalam soal yaitu pada pola keberapa untuk banyaknya pohon apel samadengan banyaknya pohon pinus. Oleh karena itu, saya menyelesaikannya dalam bentuk tabel dan kemudian menjabarkannya

$P_{6}:$ Kenapa menyelesaikannya dalam bentuk tabel?

$P M_{6}$ : Untuk mempermudah mengerjakan dan sesuai arahan yang ada di soal juga

$P_{7}$ : Selanjutnya, bagaimana jawabanmu ketika Pak Petani membuat kebun yang lebih besar lagi. Mana yang akan meningkat lebih cepat antara banyaknya jumlah pohon apel dengan pohon pinus?

$P M_{7}$ : Banyak jumlah pohon pinus dibandingkan pohon apel

$P_{8} \quad: \quad$ Jelaskan mengapa demikian?

$P M_{8}$ : Karena dari hasil perhitungan saya $\mathrm{Bu}$ yang ada ditabel terlihat jelas bahwa dari $\mathrm{n}=1, \cdot \cdot$ $\cdot, \mathrm{n}=7$ banyaknya hasil terlihat pada pohon pinus sehingga saya menyimpulkannya pohon pinus yang lebih cepat meningkat

Berdasarkan hasil wawancara peneliti terhadap subjek PM di atas menunjukan bahwa: (1) subjek mampu menjelaskan dengan tepat langkah menemukan solusi matematika dari ilustrasi yang ada melalui perhitungan tabel (2) subjek tetap melakukan kesalahan dalam menjelaskan mana yang lebih cepat meningkat antara pohon apel dengan pohon pinus.

$P_{9} \quad$ : Dari hasil yang kamu dapatkan dari proses penyelesaian, jelaskan kesimpulannya

$P M_{9} \quad$ : Jadi dari langkah penyelesaiaan yang saya kerjakan dalam bentuk tabel diperoleh bahwa banyaknya pohon apel $=n^{2}$ dan banyaknya pohon pinus $=8 \mathrm{n}$ sehingga banyaknya pohon apel samadengan banyaknya pohon pinus yaitu berada pada $\mathrm{n}=8$

$P_{10}$ : Apakah ada lagi kesimpulan yang lain?

$P M_{10}$ : Tidak ada bu, cuman itu saja

Berdasarkan hasil wawancara peneliti terhadap subjek PM di atas menunjukan bahwa subjek sudah tepat dalam menarik kesimpulan untuk bagian yang ditanyakan pertama namun pada bagian yang ditanyakan kedua subjek tidak bisa menarik kesimpulannya.

Tabel 3 Analisis Jawaban Hasil Wawancara Subjek PM

\begin{tabular}{|c|c|}
\hline $\begin{array}{c}\text { Tahapan } \\
\text { Kemampuan } \\
\text { Literasi } \\
\text { Matematika }\end{array}$ & $\begin{array}{c}\text { Analisis Jawaban } \\
\text { Hasil } \\
\text { WawancaraSubjek } \\
\text { PM }\end{array}$ \\
\hline $\begin{array}{l}\text { Merumuskan } \\
\text { masalah secara } \\
\text { matematis }\end{array}$ & $\begin{array}{lr}\text { Subjek PM mampu } \\
\text { memahami } & \text { struktur } \\
\text { matematika } & \text { dalam } \\
\text { permasalah atau situasi yang } \\
\text { ada dengan } r \text { tepat } \\
\text { menjelaskan apa yang } \\
\text { diketahui dan ditanyakan } \\
\text { dalam soal. }\end{array}$ \\
\hline $\begin{array}{l}\text { Menerapkan } \\
\text { konsep, fakta, } \\
\text { prosedur dan } \\
\text { penalaran }\end{array}$ & $\begin{array}{l}\text { Subjek PM mampu } \\
\text { merancang } \\
\text { mengimplementasikan } \\
\text { strategi untuk menemukan } \\
\text { solusi matematika walaupun } \\
\text { dengan menjelaskannya } \\
\text { dengan tepat }\end{array}$ \\
\hline $\begin{array}{l}\text { Menafsirkan, } \\
\text { menerapkan } \\
\text { dan } \\
\text { mengevaluasi } \\
\text { hasil } \\
\text { perhitungan }\end{array}$ & $\begin{array}{l}\text { Subjek sudah benar } \\
\text { menjelaskan kesimpulan } \\
\text { pertama sesuai dengan hasil } \\
\text { penyelesaian r yang } \\
\text { didapatkan subjek pada tabel } \\
\text { namun untuk kesimpulan } \\
\text { ke-dua subjek tidak bisa } \\
\text { menjelaskannya }\end{array}$ \\
\hline Kesimpulan & $\begin{array}{lr}\text { Subjek PM } & \text { mampu } \\
\text { melakukan } & \text { tahapan } \\
\text { kemampuan } & \text { literasi } \\
\text { matematika namun belum } \\
\text { maksimal }\end{array}$ \\
\hline
\end{tabular}




\section{Triangulasi}

Berikut ini penyajian dalam bentuk tabel mengenai triangulasi data dari hasil tes tertulis dan wawancara:

\begin{tabular}{|c|c|c|}
\hline $\begin{array}{c}\text { Tahapan } \\
\text { Kemampuan } \\
\text { Literasi } \\
\text { Matematika }\end{array}$ & $\begin{array}{c}\text { Analisis Hasil } \\
\text { Jawaban Tertulis } \\
\text { Subjek PM }\end{array}$ & $\begin{array}{c}\text { Analisis Hasil } \\
\text { Wawancara Subjek } \\
\text { PM }\end{array}$ \\
\hline $\begin{array}{l}\text { Merumuskan } \\
\text { masalah } \\
\text { secara } \\
\text { matematis }\end{array}$ & $\begin{array}{lr}\text { Subjek PM } & \text { mampu } \\
\text { memahami } & \text { struktur } \\
\text { matematika } & \text { dalam } \\
\text { permasalah } & \text { atau } \\
\text { situasi yang } & \text { ada } \\
\text { dengan } & \text { tepat } \\
\text { menuliskan apa } & \text { yang } \\
\text { diketahui } & \text { dan } \\
\text { ditanyakan } & \text { dalam } \\
\text { soal. } & \\
\end{array}$ & $\begin{array}{lr}\text { Subjek PM } & \text { mampu } \\
\text { memahami } & \text { struktur } \\
\text { matematika } & \text { dalam } \\
\text { permasalah } & \text { atau } \\
\text { situasi yang } & \text { ada } \\
\text { dengan } & \text { tepat } \\
\text { menjelaskan apa yang } \\
\text { diketahui } & \text { dan } \\
\text { ditanyakan } & \text { dalam } \\
\text { soal. } & \\
\end{array}$ \\
\hline $\begin{array}{l}\text { Menerapkan } \\
\text { konsep, fakta, } \\
\text { prosedur dan } \\
\text { penalaran }\end{array}$ & $\begin{array}{lr}\text { Pada } & \text { Gambar } \\
\text { Subjek PM } & \text { mampu } \\
\text { merancang } & \text { dan } \\
\text { mengimplementasikan } \\
\text { strategi } & \text { untuk } \\
\text { menemukan } & \text { solusi } \\
\text { matematika } & \text { walaupun } \\
\text { sedikit } & \text { melakukan } \\
\text { kekeliruan } & \text { dalam } \\
\text { menuliskan } & \text { hasil } \\
\text { perkalian yang salah }\end{array}$ & $\begin{array}{lr}\text { Subjek PM mampu } \\
\text { merancang ran } \\
\text { mengimplementasikan } \\
\text { strategi } \\
\text { menemukan untuk } \\
\text { matematika walaupun } \\
\text { dengan } \\
\text { menjelaskannya } \\
\text { dengan tepat }\end{array}$ \\
\hline $\begin{array}{l}\text { Menafsirkan, } \\
\text { menerapkan } \\
\text { dan } \\
\text { mengevaluasi } \\
\text { hasil } \\
\text { perhitungan }\end{array}$ & $\begin{array}{lr}\text { Pada Gambar } & 1.4 \\
\text { subjek sudah } & \text { benar } \\
\text { menuliskan } & \\
\text { kesimpulan } & \text { sesuai } \\
\text { dengan } & \text { hasil } \\
\text { penyelesaian } & \text { yang } \\
\text { didapatkan } & \text { subjek } \\
\text { namun pada } & \text { Gambar } \\
1.4 \quad \text { subjek } & \text { kurang } \\
\text { tepat } & \text { dalam } \\
\text { menuliskan } & \\
\text { kesimpulannya } & \\
\end{array}$ & $\begin{array}{l}\text { Subjek sudah benar } \\
\text { menjelaskan } \\
\text { kesimpulan pertama } \\
\text { sesuai dengan hasil } \\
\text { penyelesaian yang } \\
\text { didapatkan subjek } \\
\text { pada tabel namun } \\
\text { untuk kesimpulan ke- } \\
\text { dua subjek tidak bisa } \\
\text { menjelaskannya }\end{array}$ \\
\hline Kesin & \multicolumn{2}{|c|}{$\begin{array}{l}\text { Subjek PM mampu melakukan tahapan } \\
\text { kemampuan literasi matematika namun } \\
\text { belum maksimal }\end{array}$} \\
\hline
\end{tabular}

Hasil aktivitas data yang diperoleh melalui tes tertulis dan wawancara pada tabel di atas menunjukan bahwa subjek PM mampu melakukan tahapan kemampuan literasi matematika namun belum maksimal. Diketahui bahwa untuk tahapan pertama subjek PM mampu merumuskan masalah secara matematis dengan tepat menentukan apa yang diketahui dan ditanyakan dalam soal. Kemudian untuk tahapan kedua subjek PM mampu menerapkan konsep, fakta, prosedur dan penalaran untuk menyelesaikan permasalahan dalam soal. Hal tersebut sesuai dengan hasil penelitian yang diperoleh Wati., Sugiyanti \& Muhtarom (2019), dan juga Zahro, et al (2020) yang mana tahap pertama subjek mampu merumuskan masalah secara matematis dan pada tahap kedua juga subjek mampu menerapkan konsep, fakta, prosedur dan penalaran untuk mendapatkan hasil perhitungan. Pada tahap ketiga subjek PM mampu membuat kesimpulan namun belum tepat. Hal ini didukung oleh hasil penelitian yang dilakukan Wati., Sugiyanti \& Muhtarom (2019)

\section{KESIMPULAN}

Berdasarkan uraian pembahasan yang telah dilakukan diatas maka dapat disimpulkan bahwa hasil yang mampu dicapai pada tahapan kemampuan literasi matematika dalam memecahkan masalah matematika sudah cukup baik. Untuk tahap pertama subjek PM mampu memahami struktur matematika dalam permasalah atau situasi yang ada dengan tepat menunjukan apa yang diketahui dan ditanyakan dalam soal. Tahap kedua subjek PM mampu merancang dan mengimplementasikan strategi dengan tepat untuk menemukan solusi matematika dan tahap ketiga yaitu subjek PM masih kurang tepat dalam menarik kesimpulan dari hasil jawaban yang diperolehnya.

\section{SARAN}

Berdasarkan hasil penelitian kemampuan literasi matematika dalam memecahkan masalah matematika, maka dapat diberikan beberapa saran yaitu guru perlu memberikan soal nonrutin untuk melatih para siswa memecahkan masalah karena dengan begitu siswa dituntut untuk bernalar dan berpikir dalam menemukan solusi dan ketika diberikan soal nonrutin terus-menerus maka siswa akan terbiasa untuk menyelesaikan permasalahan yang ada dikehidupan sehari-hari.

\section{UCAPAN TERIMAKASIH}

Peneliti mengucapkan terimakasih kepada pihak - pihak yang telah membantu terlaksananya dan tercapainya penelitian ini terutama untuk Kepala Sekolah dan Guru Matematika SMP Negeri 2 Woha dan tidak lupa kami juga mengucapkan banyak terimakasih kepada Jurnal yang memberikan kesempatan kepada saya untuk men-submit artikel.

\section{DAFTAR PUSTAKA}

Afriyanti, I., Wardono, \& Kartono. (2018). Pengembangan Literasi Matematika Mengacu PISA Melalui Pembelajaran Abad Ke-21 Berbasis Teknologi. PRISMA, Prosiding 
Seminar Nasional Matematika, 1, 608-617.

De Lange, J. (2003). Mathematics for Literacy. Quantitative Literacy: Why Numeracy Matters for Schools and Colleges, 75-89. http://www.maa.org/ql/pgs75 89.pdf.

Dewantara, A. H. (2019). Analisis Konten Buku Teks Matematika K-13 Terkait Potensi Pengembangan Literasi Matematika. Didaktika: Jurnal Kependidikan, 13(2), 112-130.

Fathani, A.H. (2016). Pengembangan Literasi Matematika Sekolah dalam Perspektif Multiple Intelligences, Jurnal EduSains, vol(4), no.2, 136150.

Kemendikbud. (2019). Pendidikan Di Indonesia Belajar Dari Hasil PISA 2018. 021, 1-200.

Novita, R., Zulkardi, \& Hartono, Y. (2012). Exploring Primary Student's Problem-Solving Ability by Doing Tasks Like PISA's Question. IndoMS. J.M.E, 3(2), 133-149.

Nurvicalesti, N., Rachmani Dewi, N., \& Walid. (2019). Kemampuan Literasi Matematika pada Pembelajaran Survey, Question, Read, Reflect, Recite , Review ( SQ4R ) berpendekatan Realistik. PRISMA, Prosiding Seminar Nasional Matematika, 2, 103-108.

Ojose, B. (2011). Mathematics literacy: Are We Able to Put the Mathematics We Learn Into Everyday Use? Journal of Mathematics Education, 4(1), 89100.

Rachmantika, A. R., \& Wardono. (2019). Peran Kemampuan Berpikir Kritis Siswa Pada Pembelajaran Matematika Dengan Pemecahan Masalah. PRISMA, Prosiding Seminar Nasional Matematika, 2, 439-443.

Sari, R. H. N. (2015). Literasi Matematika: Apa, Mengapa dan Bagaimana? Seminar Nasional Matematika Dan Pendidikan Matematika, 713-720.
Sari, R. H. N., \& Wijaya, A. (2017). Mathematical Literacy of Senior High school Students in Yogyakarta. Jurnal Riset Pendidikan Matematika, 4(1), 100-107.

Stacey, K. (2011). The PISA View of Mathematical Literacy in Indonesia. IndoMS. J.M.E， 2(2), 95-126. https://doi.org/10.22342/jme.2.2.746.9 5-126

Wati, M., Sugiyanti, \& Muhtarom. (2019). Analisis Kemampuan Literasi Matematika pada Siswa Kelas VIII SMP Negeri 6 Semarang. Imajiner: Jurnal Matematika dan Pendidikan Matematika, 1(5), 97-106.

Zahro, H., Hafidah, Dhofir, \& Zayyadi, M. (2020). Gerakan Literasi Matematika daLam Peningkatan Kemampuan Pemecahan Masalah Matematis Siswa. 9(2), 165-177. 